\title{
DIONYSIUS OF HALICARNASSUS ON LYSIAS, RHETORIC AND STYLE
}

\section{I Context and Contemporaries}

Dionysius of Halicarnassus says just enough about himself to allow us to date him with confidence to the last part of the first century BCE. In the preface to his monumental work on the

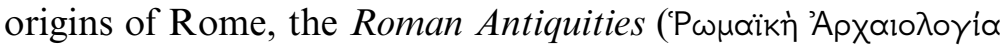
I.7.2), Dionysius writes that he arrived in Rome after the Battle of Actium either in late 30 or early 29 BCE and settled there to learn Latin, to familiarize himself with Roman literary culture, and write the history of Rome. ${ }^{\mathrm{I}}$ What he does not tell us, but what has been assumed from his literary activity, is that in Rome he 'also practiced as a teacher of rhetoric', and perhaps even 'kept an open school'.2 Hence, next to this magnum opus of Roman history, Dionysius was engaged with rhetoric and literary studies and as evidence for this activity we have his essays on ancient orators and literary criticism. ${ }^{3}$ It is these critical works in particular that will constitute the focus of the following, and in many ways culminating, chapters of this book. Altogether, ten shorter essays and treatises have come to us: five essays on ancient orators (Lysias, Isocrates, Isaeus, Demosthenes, Dinarchus) with a preface to the work On the Ancient Orators, ${ }^{4}$ an essay on Thucydides, a treatise on

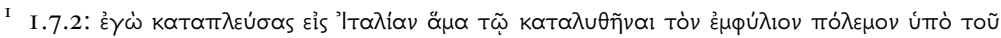

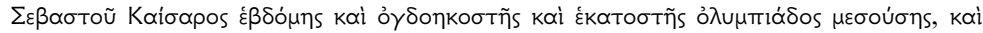

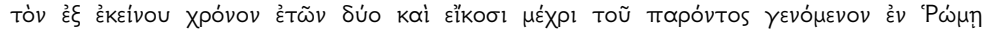

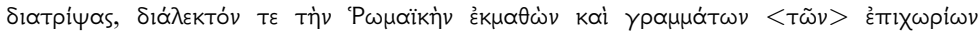

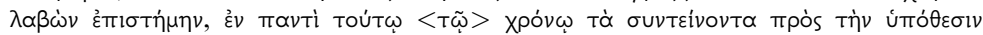

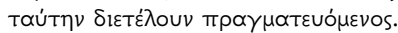

2 Bonner (I939), 2. Egger (I902), 7 rightly draws attention to the fact that we have no actual evidence that Dionysius had a school.

3 A general introduction to Dionysius' critical essays is Bonner (I939) and Usher (I974).

${ }^{4}$ Dionysius' essay on Dinarchus was part of a later project, as he himself writes in Dinarchus (I.I).

I 76 
literary composition (De compositione verborum), and finally three letters (two letters to Ammaius and one to Gnaeus Pompeius). The relative chronology of these works, as well as their relation to his Antiquities, is uncertain and scholars have contended over the probable order of his oeuvre. ${ }^{5}$ To an extent we can rely here on Dionysius' own words at the end of the preface to On the Ancient Orators (4.5), where he introduces his project:

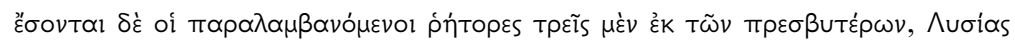

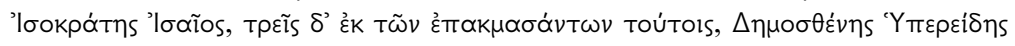

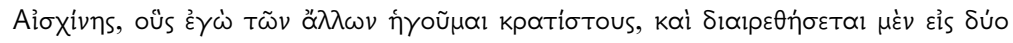

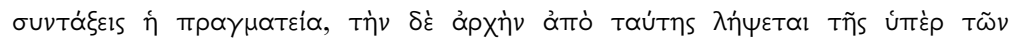

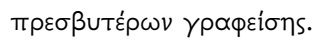

The orators to be compared will be three from the earlier generation, Lysias, Isocrates and Isaeus, and three from those who flourished after these, Demosthenes, Hyperides and Aeschines, whom I consider to be best of others. This work will be divided into two parts, the first dealing with the writings of the older orators.

As Usher notices, there are plenty of cross-references between these works to confirm that this was the order in which Dionysius wrote at least the first three essays. ${ }^{6}$ With other essays we tread a more problematic ground: the longer but incomplete essay Demosthenes has been considered as part of the same project (On the Ancient Orators), ${ }^{7}$ but the apparent inconsistencies within the work have brought some scholars to consider it either as an independent and separate work on Demosthenes, ${ }^{8}$ or as consisting of two separate treatises, Demosthenes I (I-33) and II (34-58) respectively. ${ }^{9}$ For the

5 E.g. Roberts (I90I), 6; Bonner (I939), $38 . \quad{ }^{6}$ Usher (I974), xxiii.

7 E.g. Usher (I974), xxiii; Bonner (I939), 3I-3. ${ }_{8}^{8}$ Tukey (I909).

9 Aujac (I988), I6-24. van Wyk Cronjé (I986), I23-33 argues that the work comprised four (rather than two) parts. It has to be said that the second part of the work is somewhat similar to Dionysius' De compositione verborum $(\mathrm{CV})$, which in turn makes references back to Demosthenes 5-7. According to the standard interpretation of their relationship, Dionysius had interrupted his work on Demosthenes in order to write his essay $C V$ (e.g. Kim 20I4, 37I n. 38). Recently, however, de Jonge (2008), 22-3 has proposed an appealing solution, namely that Dionysius might have been 'working on the two treatises at the same time', and this solution might best explain the difficulties relating to both texts. 


\section{Dionysius of Halicarnassus on Lysias}

present purpose, the question of the relative chronology and relationship between Dionysius' Demosthenes and $C V$ is relevant in as far as it may shed light on the development of Dionysius' thought and methodology through his use of critical terminology. ${ }^{\text {IO }}$ The general consensus, which will be challenged in this chapter, sees 'a clear evolution in Dionysius' critical methods, which become more sophisticated in his later works'. ${ }^{\text {I }}$ According to this view, Dionysius' rhetorical works belong to the last period of his activity and they have been understood as a natural result of Dionysius' long career and work in Rome, where it is highly likely that his interaction with peers contributed to this intellectual development. ${ }^{\text {I2 }}$ As will be argued below, Dionysius' rhetorical treatises offer us instead an insight into a developed understanding of the Attic orators from their first instalment (On Lysias) onwards. Thus, instead of seeing the essays progressing from one orator to another as an advancement of the critical competences of the author, it appears much more appropriate to view the progress from the perspective of a potential student. Dionysius emerges, then, as a writer and a teacher who is much more sensitive to the interests and abilities of his students than perhaps granted thus far.

Many more debates around Dionysius' critical works concern his intellectual circle, which could tell us something about the nature of his essays as well as their intended audience and circumstance for delivery. ${ }^{\mathrm{I}}$ Unfortunately, the evidence is very scarce. However, even though most of the personages Dionysius mentions in his work are unknown to us, ${ }^{\mathrm{I} 4}$ the various names themselves indicate a possibly mixed Greek-Roman

Io The chronology of Dionysius' critical works and the way it reflects on the development of his critical acumen are the focus of Bonner (I939), Lebel (I973) and Damon (I99I).

${ }^{11}$ De Jonge (2008), 2I. $\quad{ }^{12}$ Schenkeveld (I983), 69.

${ }^{13}$ For different positions on Dionysius' audience, see Bowersock (I965), I3 I; Gabba (I982), 79-80; Schultze (I986); and most recently (and persuasively) de Jonge and Hunter (20I8), 32-3.

${ }^{14}$ There are important exceptions, such as Quintus Aelius Tubero. Bonner (I939), 4-5. For Tubero, see Cornell (2013).

I 78 


\section{Context and Contemporaries}

audience. ${ }^{\mathrm{I}}$ Within the deeply polarizing debates about the intended readers and audience of Dionysius' works, a careful assessment of the existing evidence seems to confirm that Dionysius wrote for readers of elite status who had competent Greek, regardless of their ethnic background and citizen-

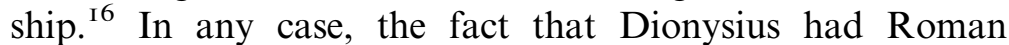
students, ${ }^{17}$ for whom Greek was desirable and within reach, also suggests that he was well informed about the contemporary educational setting in Rome, sensitive to the needs of his students and had a positive reputation, enough to appear attractive to them.

Dionysius' intellectual network is as fascinating as it is complicated. ${ }^{18}$ It would be wonderful to know more about other scholars and intellectuals Dionysius met, and read, and exchanged his ideas with. Unfortunately, a lot of that information will have to remain speculative. Yet, from his commitment to history and rhetoric and from what he tells us about his migration to Rome in the beginning of the Antiquities, we can assume that he was well read in Roman history, knew the works of the orators (especially Cicero) and was familiar with the poetic and rhetorical criticism of Roman intellectuals. ${ }^{\text {I9 }}$ Within this network there is one person in particular that deserves heightened attention in the context of this present

${ }^{15}$ It is unclear, for example, whether Ammaeus, the recipient of two of Dionysius' letters and the preface to On the Ancient Orators, was Greek or Roman (Hidber I 996,7$)$. Equally unclear is the identity of $\mathrm{Cn}$. Pompeius Geminus. Dionysius' student Metilius Rufus, however, was a Roman as was Q. Aelius Tubero, a historian, lawyer and the addressee of Dionysius' On Thucydides. See more in Bowersock (I965), Hidber (I996), de Jonge (2008), 26-8.

16 'Introduction' in de Jonge and Hunter (2018), 32-3. See also Luraghi (2003) on the addressees of his historical works and Weaire (2005) of the rhetorical ones.

${ }^{17}$ From the little information we have about Dionysius' teaching environment, we know that at least one of his students came from a Roman elite family (De comp. 20). Bonner (I939), 2 thinks it likely that Dionysius had a school of rhetoric and taught for a fee; Schultze (I986), I23-4 is more skeptical. For a balanced account in-between the two positions, see Weaire (2005).

${ }^{18}$ Unlike the concept of a 'circle' which Wisse (I995), 78-80 has shown to carry associations with patronage, I will use 'network' to refer to Dionysius' intellectual environment more generally. For a thorough and persuasive analysis of the classicizing aspects of Dionysius' community-creation, see Wiater (20I I), chap. 5.I.

I9 See, for example, de Jonge (2008). 
discussion - Caecilius of Caleacte. ${ }^{20}$ As far as we can tell, Caecilius was writing both history and literary criticism. ${ }^{2 \mathrm{I}} \mathrm{He}$ seems to have also made use of the comparative method in literary criticism, synkrisis, which is well on display also in Dionysius' writings, and which might have been regarded as an innovation over traditional criticism. ${ }^{22}$ Some scholars have argued that Caecilius was the creator of the canon of ten orators, ${ }^{23}$ though given the very sparse information we have on Caecilius' work, this argument has not won universal acceptance and at this stage will have to remain a speculation. Finally, in his works on literary criticism Caecilius appears to have been particularly invested in the Atticist-Asianist controversy and the Suda attributes several works to Caecilius that may have treated this subject from different perspectives. ${ }^{24}$ There is one more important aspect to mention here in relation to the relevance of Caecilius' criticism of Dionysius. Namely, Caecilius was credited by Ps. Longinus with championing Lysias as the supreme Attic stylist. Despite the fact that the Suda does not list a work of Caecilius explicitly focusing on Lysias, Ps. Longinus tells us that Caecilius had written several works on Lysias, and points out that in these ( $\dot{\varepsilon} \nu$ Toĩs úmè

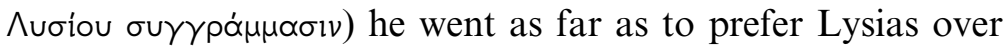

${ }^{20}$ On Caecilius, see also Kennedy (I972), 364-9; O'Sullivan (I997) on Caecilius as the originator of the canon of ten orators; Heath (1998) on Caecilius as a source for Photius; and Innes (2002) with de Jonge (2012) on Caecilius and Ps. Longinus. For a recent edition, see Woerther (2015) who also provides an insightful introduction to the critic in context (cf. Woerther 2013 on editing Caecilius' fragments).

${ }^{21}$ Roberts (I897), 303-4.

${ }^{22}$ Bonner (I939), 9-IO. On synkrisis see Focke (I923) and now also de Jonge (20I8a) on the comparison between Cicero and Demosthenes among ancient literary critics.

${ }^{23}$ O'Sullivan (I997) is among the few modern scholars who have argued in favor of seeing Caecilius as the originator of the canon of ten orators. Most have remained skeptical about our ability to say anything more affirmative about Caecilius' role in canon-making. See most recently Woerther (2015), xxxii, and Matijašić (20I8), 27.

${ }^{24}$ From his works that are unmistakably concerned with the Asianist-Atticist contro-

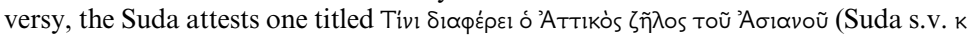
I I65 and Ofenloch fr. 6). It may well be (so Roberts I897, 304), however, that a

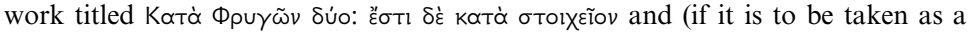

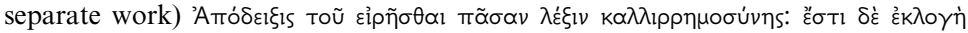

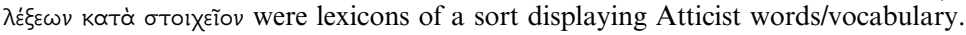
See also Kennedy (I972), 364-9. 


\section{Context and Contemporaries}

Plato. $^{25}$ It is very plausible that Ps. Longinus had misrepresented Caecilius' critical position on this matter, especially

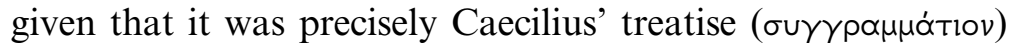
on the sublime which prompted Ps. Longinus - or so he claims - to write his work as a response to him (On the Sublime I.I). In other words, Caecilius' role in the whole of On the Sublime is one of an intellectual foil against which Ps. Longinus expresses his own views on the topic. That Caecilius might have had a more nuanced position on Lysias is suggested by Photius, who tells us that Caecilius did not approve of Lysias' arrangement and found it lacking in power. ${ }^{26}$ Innes has argued convincingly that it is highly unlikely that Lysias was considered a model for sublimity in Caecilius' treatise on the subject, and that it is very probable that he regarded Demosthenes instead as most appropriate for this role. ${ }^{27} \mathrm{Be}$ that as it may, Caecilius surely demonstrated high regard for

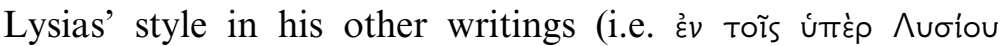

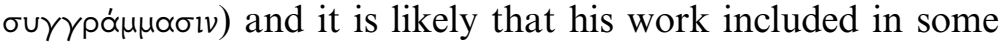
form a comparison between Lysias and Plato.

All the previous aspects indicate that Dionysius and Caecilius had much in common as regards their intellectual work. Indeed, given that the focus of their literary criticism has many points in common, scholars have long wondered whether they were rivals or friends. ${ }^{28}$ Dionysius refers to Caecilius explicitly in the Letter to Gn. Pompeius and calls

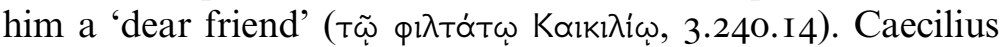
seems to be brought into the discussion as an authoritative critic whose agreement will further bolster Dionysius' divisive discussion about the comparison between Herodotus and

25 Ps. Longinus On the Sublime 32.8. Ps. Longinus' wording is very strong and highly emotional: 'he loved Lysias not even as he did himself, and at the same time he hated Plato and all his works more than he loved Lysias' (

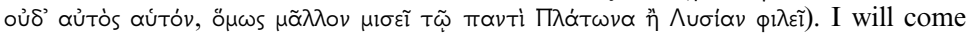
back to the recurring Lysias/Plato comparison below.

${ }^{26}$ Photius Bibliotheke 489aI3-17. Caecilius is here listed among the critics of Lysias, which suggests that his work on Lysias might have contained a more nuanced account of the orator than presented in Ps. Longinus.

${ }^{27}$ Innes (2002). $\quad{ }^{28}$ On this question, see further Bonner (I939), 6-Io. 


\section{Dionysius of Halicarnassus on Lysias}

Thucydides. ${ }^{29}$ This might as well just settle the discussion for now. Taking into consideration their shared views (on Lysias, Plato and Demosthenes) and methods (e.g. synkrisis), it is more likely that Caecilius was a friendly collaborator and an influence rather than a bitter rival.

What emerges from this previous discussion is that Dionysius was part of a busy intellectual network, which included many critics and historians who were invested in thinking about the ancient rhetorical tradition through classical Greek writers, playing them against each other and making them representatives of certain stylistic approaches that always also reflected political ideologies. Lysias' treatment in these contexts appears to have been particularly controversial and naturally invited critics to go back to that previous moment when Lysias' style and rhetorical contributions were subjected to intense commentary - Plato's Phaedrus. Formulating views about Lysias also meant critically engaging with Plato's Phaedrus. It is therefore not at all surprising that whenever critics of that period form a strong opinion about Lysias, they also ended up having strong views about Plato and Isocrates. ${ }^{30}$ Since Plato had in that dialogue posited the two figures at opposite ends of the rhetorical discourse (as much as they were at the opposite sides of the dialogue: Lysias in the beginning, Isocrates at the end), critics soon found themselves participating in this double axis of literary-critical analysis: Lysias and Isocrates required interpretation as representatives of opposing views of rhetoric, and Plato demanded response as an important predecessor in assessing their success and relevance to the contemporary moment. In the centuries between Plato and Dionysius, we have found sections and snippets from various writers,

29 If indeed Demosthenes was the most illustrious stylist also for Caecilius, then Dionysius' reference to the orator as an imitator (of sorts) of Thucydides surely softens his preceding criticism of the historian.

${ }^{30}$ Hunter (20I2), I5I-84 is a must-read analysis of the ancient criticism of Plato's style and of the reception of Plato's Phaedrus. Hunter masterfully demonstrates how Plato's Phaedrus, which offered criticisms of Lysias and Isocrates, was soon in the critical tradition itself subjected to criticisms and assessments of its author's style. 
second-hand accounts and spurious fragments that have all individually supported an interpretation that regards Lysias and Isocrates as important (if not central) figures for the broader conceptualization of the rhetorical tradition. However, it is not until Dionysius of Halicarnassus and his classicizing ambition to rethink the preceding rhetorical tradition and appropriate it to the contemporary Roman context that we see a fully fledged engagement with the triad - Lysias, Isocrates and Plato - emerging.

Curiously, of all Dionysius' works, his critical essays on ancient orators (with the exception of his preface to On the Ancient Orators) and particularly his essays on Lysias, Isocrates and Isaeus, have received the least scholarly attention. ${ }^{3 \mathrm{I}}$ This is surprising, because Dionysius' programmatic approach to the rhetorical tradition, and his aim to map it out for his contemporaries that is on display from the preface onwards, invite us to follow his discussion from the beginning and not to skip any building block on the way. This chapter goes further than that and will examine the way in which his essays on Lysias and Isocrates function as the foundational base for Dionysius' creation of the rhetorical tradition.

\subsection{Dionysius and Lysias}

As Dionysius announces in the preface to On the Ancient Orators, Lysias is the first contribution to this larger project on ancient orators and historians that aims to benefit the general public with a worthy topic that has not been discussed

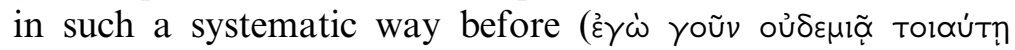

${ }^{31}$ I thus disagree with Wiater's (20 I I, I) evaluation of Dionysian scholarship when he says that '70 years after the publication of Bonner's treatise, Dionysius' linguistic and rhetorical theories seem to have been exhaustively explored'. It is true that there has been a significant interest in Dionysius' linguistic and rhetorical work and important work has been done on the De compositione verborum (esp. de Jonge 2008). However, his shorter essays on Attic orators have not received much focused attention and his engagement with individual orators has been rather unevenly discussed in recent scholarship. Wiater (20II) himself goes on, of course, to offer detailed and insightful readings of the rhetorical essays in his overarching discussion of Dionysius' classicism. 


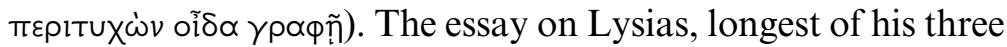
essays on the earlier generation of ancient orators, is roughly divided into two larger sections, the first dedicated to Dionysius' assessment of Lysias' speeches by reference to specific characteristics of Lysias' style, the second part analyzing examples from Lysias' speeches to sustain claims made in the first part. Additionally, the essay contains a very brief section on Lysias' biography with a short discussion of his dates. Usher points out that in this biographical section Dionysius is simply reproducing 'uncritically facts recorded by earlier biographers'. ${ }^{32}$ As we have seen before, however, Lysias was a rather hidden figure (also because of his profession as a speechwriter) already for earlier authors, so that recovering reliable biographical facts about his life was hard and existing accounts were mostly full of controversy. ${ }^{33}$ Either way, we are given only the very basic information about Lysias' life before Dionysius proceeds to discuss the orator's work and the literary qualities of his style.

As a brief side note, it is noteworthy that none of the speeches mentioned and discussed by Dionysius in this essay are those preserved to us by the manuscript tradition. Of the three speeches quoted at length in the second half of the essay, the first three sections of speech 32 (Against Diogeiton) are attested also in Syrianus' commentary on Hermogenes' Peri ideon (88.I5-89.I5), sections of speech 33 (Olympiacus) are preserved in Diodorus Siculus (I4.I09), Ps. Plutarch's Lives of Ten Orators (836d) and in Theon's Progymnasmata (63), and for speech 34 (On Preserving the Ancestral Constitution) Dionysius is our only source. This is perhaps not surprising if we remember that Dionysius had a very wide selection of

${ }^{32}$ Usher (1974), 2 I n. I. Usher draws attention here to another passage (First Letter to Ammaeus 3) where Dionysius explicitly mentions biographers on whom he relies for biographical accounts, in this particular case for Demosthenes and Aristotle.

33 Dionysius might have simply wanted to avoid getting involved in this discussion so as to keep the essay from expanding further. There is indeed a preoccupation with time and length in these first three essays, in a way that we do not find in the later works. Could this be taken to suggest something about the role of these orators in rhetorical teaching, where they might have been used to set the ground for further study? 
Lysianic speeches to choose from, so that his choice was understandably different from those who later put together the collection of Lysias' speeches. And yet it is still somewhat unexpected that the later tradition did not pick up the Lysianic speeches held in such high regard by Dionysius. One more aspect is worth mentioning here: namely, Dionysius' varying enthusiasm for the speeches he quotes in this essay. He furnishes all three speeches with a brief introduction, but only provides comments on the forensic one. The excerpts from the other two speeches are much shorter and are not accompanied with a single critical comment. This lack of close critical engagement with the speeches has led some scholars to argue that at the time Dionysius wrote Lysias his critical methodology was not yet developed to the heights we see in his later essays. We should also note, however, that Dionysius is consciously and openly prioritizing Lysias' forensic work over other genres (3.7.), so that the lack of engagement with his other speeches is an expected result of his fashioning of the image of Lysias as a forensic author.

Dionysius portrays an image of Lysias as an active and established writer in a variety of different genres. According to Dionysius, Lysias 'wrote many well-arranged speeches to the law courts and the council and the assembly, as well as

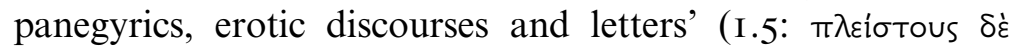

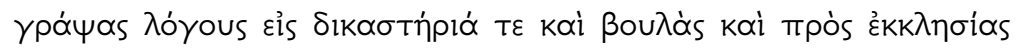

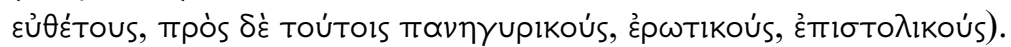
Dionysius continues: 'he overshadowed the fame of those orators who came before him and those who blossomed in his own time, leaving not many opportunities to improve for those to come in all these forms of writing, by Zeus not even in

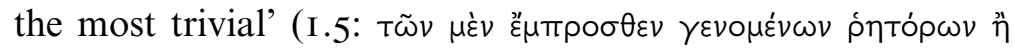

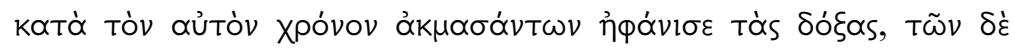

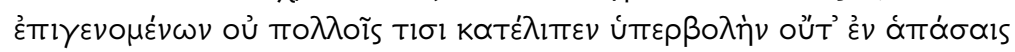

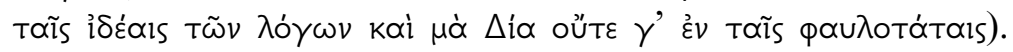
Lysias was, then, a well-rounded writer, accomplished in all genres, and yet Dionysius consistently emphasizes Lysias' excellence in court speeches and the most trivial matters

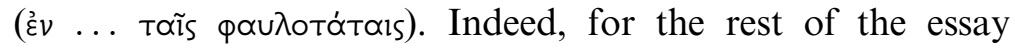


Dionysius leaves to one side, without further comment, 'his letters, his amatory discourses' and 'the other works which he wrote for amusement (3.7: $\mu \varepsilon \tau \dot{\alpha} \pi \alpha \_\delta \tilde{\alpha} s$ है $\left.\gamma \rho \alpha \psi \varepsilon v\right)$ ', and focuses only on 'the serious speeches which he wrote for the law courts

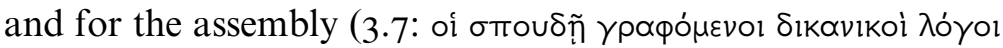

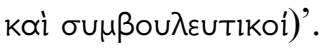

With regard to Dionysius' critical method, as far as we can tell from this essay, he seems to have been an eclectic, drawing from a variety of different critical approaches and not subscribing to any literary or philosophical school in particular. Indeed, not only does Dionysius follow the (Peripatetic) theory of virtues of style (more below), but throughout this essay he appears to make use of many different rhetorical theories and systems: he makes productive use of Theophrastus (6. I, I4.I), of Isocrates or, perhaps more appropriately, the followers of Isocrates (I6.5), and of older rhetorical handbooks (24. I-4). In doing so, Dionysius does not seem particularly concerned to stick to one specific system of virtues and to describe Lysias according to the terminology of a particular school. Instead, as he tells us at I0.3, he could name many more virtues of style, leaving it essentially open from where he is drawing his terminology and system. Or, when analyzing the introduction to Lysias' forensic speech (24.5-7), Dionysius' comments on its success are drawn from older rhetorical handbooks and he is not at all disturbed by the level of specificity and particularity that these handbooks seem to employ, ${ }^{34}$ even though their approach seems very different from the more abstract terminology that Dionysius uses to discuss Lysias' style in this essay.

Bonner, whose seminal work on Dionysius' critical essays examines the development of his critical method, has argued that Dionysius' early essays, of which Lysias is an example, display a less developed and sophisticated methodology and

${ }^{34}$ Dionysius reports that the handbooks recommend, among other things, the following: when the defendants in a case are relatives of the plaintiffs, they should not appear malicious or vexatious; to blame the charge and the lawsuit on the opponent; to claim that the wrongs committed were great and spell out specifically how to gain a jury's benevolence. 
critical discussion than what we see in his later treatises. ${ }^{35}$ Focusing strictly on the Peripatetic theory of the virtues of style, Bonner claims that Dionysius is simply reproducing in this essay the system of virtues that he had inherited from the previous tradition. He thus connects Lysias with the mechanical use of this system in the first books of On imitation, where Dionysius, as appears from the epitome of that work that has been preserved in Dionysius' letter to Gnaeus Pompeius, had made extensive use of the theory of the virtues of style. ${ }^{36}$ While it is undoubtedly true that Dionysius' critical discussion in the Lysias appears more simplistic compared to his examination of the following authors, this may also reflect the special position of Lysias in Dionysius' critical thought. Lysias becomes a point of reference and comparison for Dionysius in his examination of all subsequent orators. In that role, it is almost inevitable that Lysias himself is far less compared to others in that first essay with the consequence that Dionysius' essay Lysias contains the fewest comparative references. It will be argued below, however, that instead of merely reflecting an initial stage of Dionysius' critical thought, this essay seems to have been used by the author to establish a point of reference for, and a connection to, all his following essays. Thus, while in Bonner's reading Dionysius' critical thought only begins to emerge in the essay, from another perspective Dionysius' Lysias could be read as laying the groundwork for his intellectual project, a foundational work which provides the background for all his subsequent examinations of ancient orators.

The theory of virtues ('apstai) of style goes back to Aristotle's identification of one single virtue of style, clarity

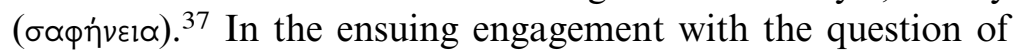

35 Bonner (I939), 39-48.

${ }^{6}$ Bonner (I939), 47. Bonner argues (37) that On Imitation was Dionysius' earliest work, because he brings up there the list of orators and refers to Lycurgus instead of Isaeus. Bonner claims that it is highly unlikely that he would have made this mistake (if mistake it is) had he already written the first instalment of his essays on the ancient orators and thus the essay on Isaeus.

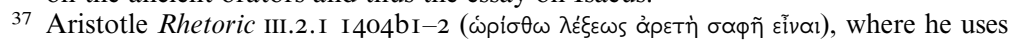
the adjective $\sigma \alpha \phi \eta \dot{s}$, and in fact does not use the noun $\sigma \alpha \varphi \eta \dot{v \varepsilon l \alpha}$ in his Rhetorica at all

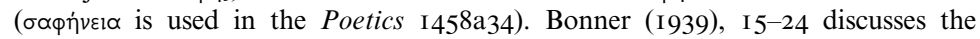




\section{Dionysius of Halicarnassus on Lysias}

style, Theophrastus had apparently broken down this virtue into four different virtues - purity of language ( $\dot{\varepsilon} \lambda \lambda \eta v 1 \sigma \mu o ́ s)$,

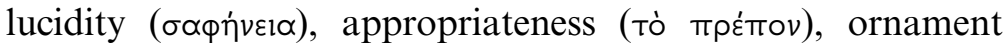

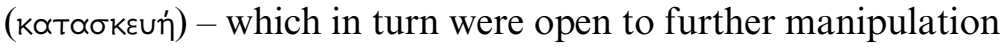
by different theorists, who added and/or omitted certain elements for their own particular purposes. That Dionysius is making use of a version of this system is clear from the lists of virtues that he provides in the essay on Lysias and, as Bonner points out, in his analysis of Herodotus and Thucydides in the epitome of On Imitation (3). Dionysius mentions this system explicitly in his later essay Thucydides (22.2-3), where he writes:

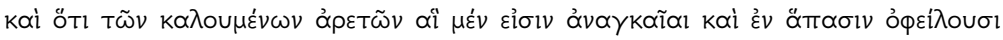

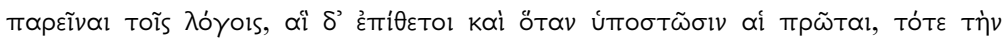

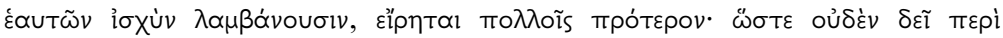

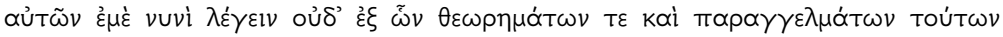

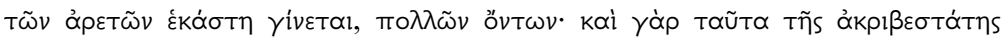

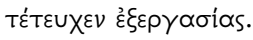

And some of the 'virtues' ascribed to style are essential, and should be present in all writing, while others are ancillary, and depend for their effect upon the presence of the essential virtues. All this has often been said before, so that it is unnecessary for me to speak of them now, or to discuss the many principles and rules on which these virtues are each founded; for these matters also have been the subject of precise and elaborate theorization.

In the letter to Gn. Pompeius, which Bonner posits in close proximity with Dionysius' Demosthenes and Thucydides, and which contains remnants of his (arguably) very early work $O n$ Imitation, Dionysius mentions this distinction between two different kinds of virtues again (3.I6-2I). He lists purity of

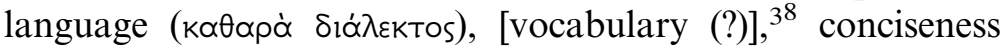

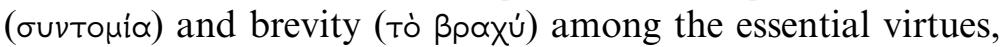
and vividness ( $\left.\dot{v} \vee \alpha \dot{\rho} \rho \varepsilon \_\right)$, imitation of character and emotions

development of the theory of virtues of style, and the following brief overview is indebted to his discussion there as well as to Schenkeveld (I964), 72-6, and Innes (I985).

$3^{8}$ There appears to be a lacuna here; Usher $(1985,383$ n. 2) suggests it may have contained the element of vocabulary as distinct from dialect; cf. the reconstruction in Aujac (I992), 92 (Gnaeus Pompeius 3.I6). 


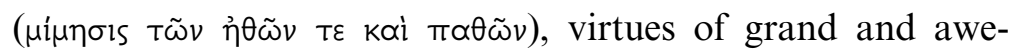

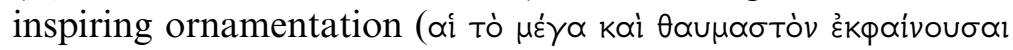

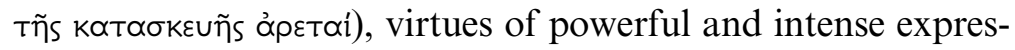

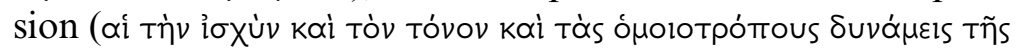

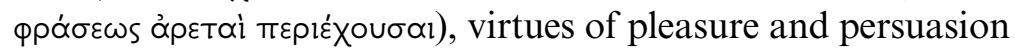
( lary virtues. Propriety is mentioned as altogether the most

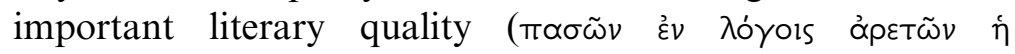

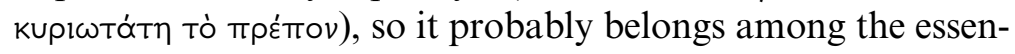
tial virtues. The main difference between these different virtues is that the 'essential' virtues have to be present in every speech, 'to make clear and manifest what one wishes to say, but they do nothing more'; the ancillary virtues have more influence

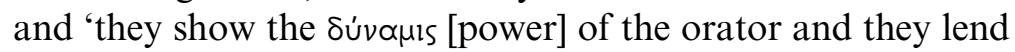
him his glory and fame'. ${ }^{39}$ Overall, however, this list gives the impression of being composed rather arbitrarily and depending heavily on specific authors, which probably results in the growing obscurity of the explanations of various 'virtues'. At any rate, there appears to be a pronounced difference in Dionysius' expression between the 'essential' and 'ancillary' virtues: the 'essential' elements are expressed in concise language, often as abstract concepts ( $\sigma \alpha \varphi \eta \dot{v} v \varepsilon 1 \alpha$ [clarity],

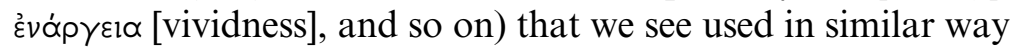
in both works (Thucydides and On Imitation), whereas the 'ancillary' virtues show more fluctuation depending on the specific author under discussion and the description of these

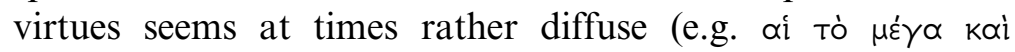

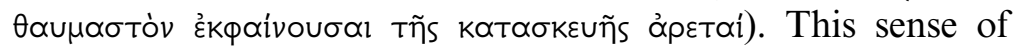
arbitrariness surrounding the 'ancillary' virtues is underscored by Dionysius' own comment at the end of the paragraph that he could provide many more examples and elements to distinguish the style of the historians, but he will save that for another opportune moment. ${ }^{40}$

Even though Dionysius does not mention the twofold division of the virtues of style into essential and ancillary

39 Schenkeveld (I964), 74. $\quad 4^{\circ}$ Letter to Gn. Pompeius 3.2 I. 


\section{Dionysius of Halicarnassus on Lysias}

explicitly in his Lysias, the proximity of the language and critical tools that Dionysius employs strongly suggests that the list he produces in this essay is indebted to that theory and connected to previously quoted passages from Dionysius' other works. ${ }^{4 I}$ The one significant difference between the virtues of style in Lysias and his Letter to Gn. Pompeius is that, compared to the latter, the former essay displays an almost definition-like distinction and treatment of the virtues: every virtue is mentioned in lucid and clear terminology, and the terms are often followed by brief explanations. The first part of the essay is largely structured around Dionysius' discussion of the following virtues of style: purity (k $\alpha \theta \alpha p o ́ s)$,

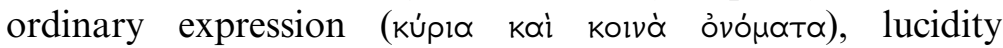

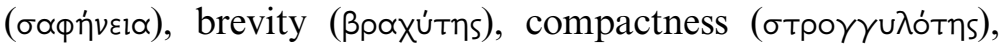

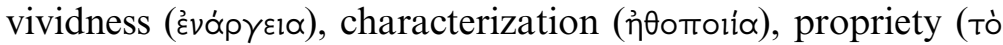

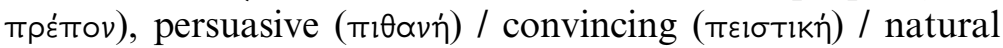

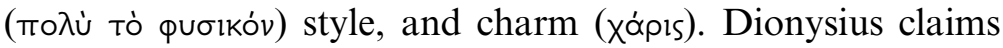
that he could mention many more relevant virtues of style, but that he will confine himself here to those mentioned. As this list clearly demonstrates, Dionysius uses, in contrast to many of the elements described in his Letter to Gn. Pompeius, a far clearer terminology which renders the discussion more structured. It should be remembered, of course, that Dionysius is here concerned with emphasizing stylistic characteristics of one author, Lysias, and that he is not engaged in comparative criticism as we see in his discussion of Herodotus and Thucydides. Whether or not this can be used to infer anything about the development of Dionysius' critical method, Dionysius' efforts to create a clear-cut critical vocabulary and method to analyze Lysias (and, by extension, all subsequent orators) have had a profound impact on later rhetorical criticism. And despite the fact that Dionysius does not mention explicitly the distinction between essential and ancillary virtues, the breakdown of the individual elements in this list seems to reveal that he is indeed following this principle.

4I Cf. Bonner (I939).

I90 
Of all Lysianic virtues Dionysius mentions purity, Lysias'

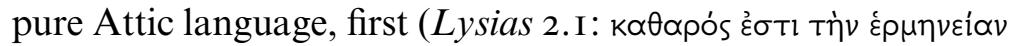

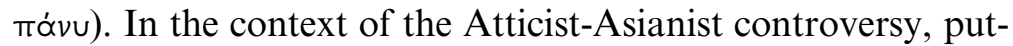
ting this quality in such a prominent position, and ahead of the Peripatetic/Aristotelian 'lucidity' ( $\sigma \alpha \varphi \eta \dot{v} v \varepsilon 1 \alpha)$, is certainly a significant move, indicating Dionysius' adherence to the classicizing attitude towards the past. ${ }^{42}$ Dionysius explicitly says that purity is 'the first and most important element in speeches'

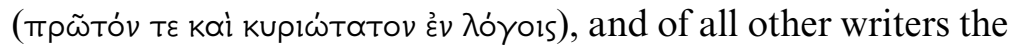
one closest to Lysias in this stylistic virtue was Isocrates. In other words, neither Plato nor Thucydides, and not even Demosthenes, is to be taken as a model for pure Attic prose. A similar Atticist-classicist background seems to lurk behind his second virtue, simplicity. In fact, Dionysius seems particularly concerned to spell out what this virtue really entails: Lysianic simplicity is deceptive, and the common words and language that he uses conceal a highly artistic prose. It is not simply everyday speech that Lysias reproduced in his speeches, ${ }^{43}$ but a highly sophisticated art of simplicity. In fact, proof of the artistic labor behind the effect of a simple and common expression is that of all the followers of Lysias it was Isocrates, this time the young Isocrates, famous for his elaborate style, who came closest to imitating Lysias' artistic and

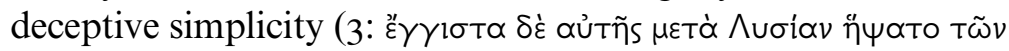

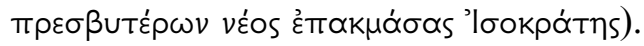

42 On Atticism, see Gelzer (I979), Gabba (I982), Hidber (I996), Porter (2006a), Kim (20I4). An excellent account of Dionysius' classicism and its relationship to Atticism is Wiater (20I I). Whether Atticism was originally a Roman or a Greek phenomenon is fiercely debated in scholarship. Hose (I999) offers an appealing solution: even if the movement itself grew out of a Roman context by Roman critics, the role models for Atticists as well as their rhetoric teachers had nevertheless been Greek. In other words, perhaps it is best to take this movement as a mixture of the two, the Roman and the Greek. More could be said about this topic, but I simply wanted to add here one more thought, which is that with Dionysius the question of Atticism comes up in dialect terms, which inevitably gives his account of Lysias and Isocrates as Atticists a rather different flavor from the one it had in Cicero.

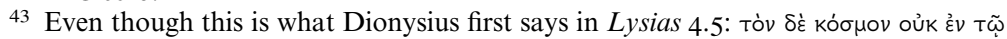

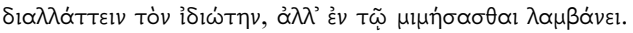




\section{Dionysius of Halicarnassus on Lysias}

Lucidity and brevity seem to conclude the list of essential virtues, for the next virtue - compactness - is already introduced in a slightly different manner. Instead of simply continuing to list further virtues, Dionysius stresses the distinctness of the next virtue, compactness, by saying 'after

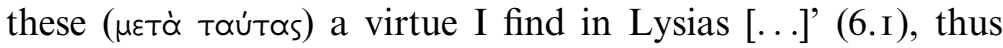
suggestively grouping together the previous four qualities and marking a new set of virtues. This virtue of style does not lend itself easily to a one-word summary: 'It is a manner of expression in which ideas are reduced to their essentials and

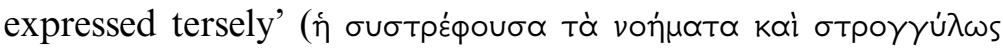

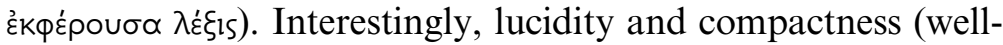
roundedness) are two elements that are also used to describe Lysias' style by Socrates in Plato's Phaedrus, where Socrates suggests that the only reason to admire the Lysianic speech is because 'all the expressions are clear and well rounded and

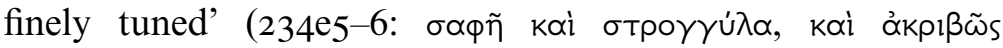

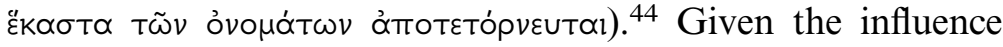
of the Phaedrus on the reception of Lysias from the fourth century onwards, it is surely no coincidence that these two elements have found such a strong presence in Dionysius' description of Lysias' virtues of style. As noted before, Dionysius is reading Plato's Phaedrus very closely and we witness here an implicit reference to the underlying importance of this dialogue for Dionysius' project. Indeed, he appears to be picking up the terminology of praise intended for Lysias (regardless of whether it was intended as such in the dialogue) and incorporates it to his own detailed analysis of Lysias' style. Making use of these two stylistic categories enables Dionysius to show himself as well informed of Lysianic criticism while at the same time demonstrating, by setting his own stylistic categories above those of Plato, the

${ }^{44}$ Whether or not Socrates' comments on Lysias' style are ironic (they surely are ironic with regard to the content and the overall success of Lysianic rhetoric), we find no evidence in ancient criticism that would suggest Socrates' analysis of Lysias and Isocrates would have been interpreted as anything but sincere assessments of their rhetoric. So too Dionysius, who seems to take Socrates' praise of Lysias' style here literally. 
importance of his own interpretation of Lysias over previous critics, and in particular over that of Plato.

The ancillary virtues in the list are selected to highlight Lysias' superiority in these elements over all other orators. In other words, for Dionysius' discussion these are specifically the Lysianic elements of style. Dionysius concludes the section on vividness ( $\varepsilon v \alpha \dot{\alpha} \rho \gamma_{\varepsilon l \alpha}$ ) by the following assessment of Lysias: 'He was the best of all the orators at observing human nature and ascribing to each type of person the appropriate emotions,

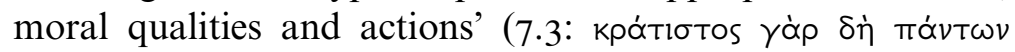

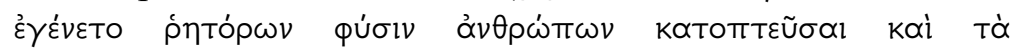

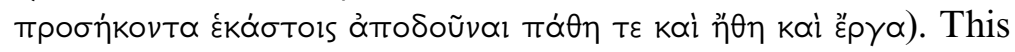
quality seems to be particularly fixed in the Peripatetic theory on virtues of style: it is alluded to in Aristotle's Rhetoric (III.II.I-4 I4IIb24-I2a9) and is defined in almost identical terms in Ps. Demetrius (209-IO). ${ }^{45}$

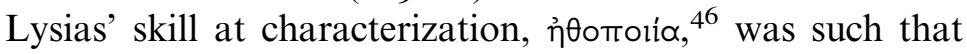
'anybody pursuing truthfulness $(\dot{\alpha} \lambda \dot{\eta} \theta \varepsilon 1 \alpha)$ and wishing to

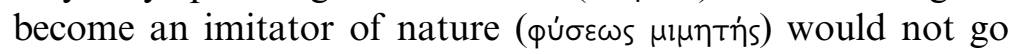
wrong in using Lysias' composition, for he will find nothing more truthful ( $\left.\alpha^{\prime} \lambda \eta \theta \varepsilon \sigma \tau \varepsilon \rho \alpha\right)$ than this' (8.7). Characterization is a particularly dense paragraph and it has also caused some scholarly debate: Dionysius' description has been read to suggest that Lysias' characters were created as general 'literary types', ${ }^{47}$ and this judgement has been contested as one-sided by those who see Lysias' speeches as displaying individual

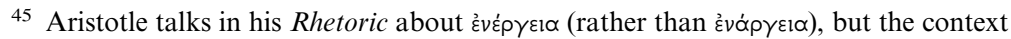
is similar: Aristotle aims to elucidate what it means to bring something 'before the

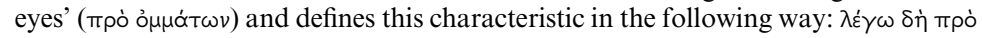

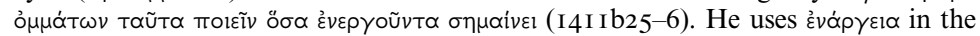
Poetics (I7 I455a22-6). A good discussion of their difference in Aristotle is Eden (I986), 7I-5.

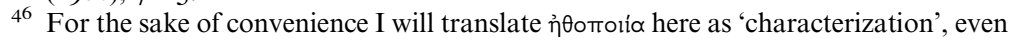
though a good case could be made for a more precise translation that would emphasize the moral qualities and normative connotations inherent in Dionysius' use of this notion.

47 See, for example, Bruns (I896), followed by Büchler (I936) and most recently Weissenberger (2003), 75. The advocates of 'individual characterization' in Lysias include most famously Usher (I965). I hope to address the topic of characterization and its use in Dionysius elsewhere. 
characterization. It is useful to remember that Dionysius is interested in identifying general features that his students can usefully imitate, which may explain his lack of engagement with what Usher labels Lysias' 'individual characterization'. In other words, the characteristics of specific historical individuals that may or may not be entirely unique to them are not really relevant for Dionysius' rhetorical interests. This section thus describes Lysias' achievement in characterization from the point of view of the general moral effect on the audience. ${ }^{48}$

In order to emphasize Lysias' character appropriations, Dionysius links Lysias' skill at characterization with the virtue of a simple and common style. That Dionysius aims to establish a link between the two virtues becomes clear when he writes that 'the impression ( $\chi \propto \alpha \alpha k T \eta \dot{\rho})$ of this harmonious [composition] seems to be somehow un-labored (åmoíntos)

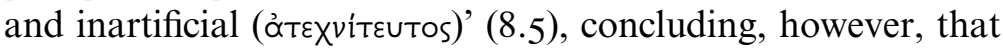

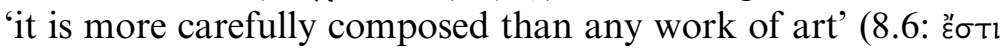

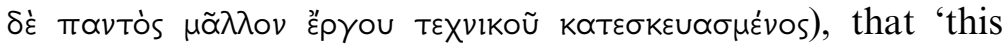

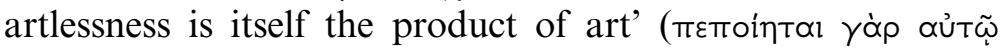
тоŨTo tò ớroíntov) and that 'it is in the very appearance of not having been composed with masterly skill that the clever-

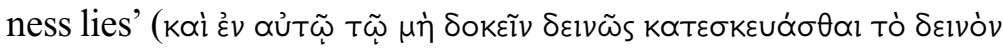
$\left.\varepsilon^{\prime \prime} \chi \varepsilon 1\right)$. This compares well with what he claimed a few passages before under the topic of 'common language/simplicity', namely that despite the apparent simplicity, Lysias 'is the most

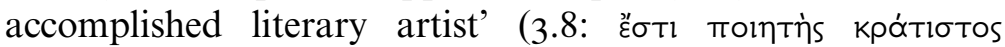
$\left.\lambda{ }^{\prime} \gamma \omega v\right)$. Dionysius' emphasis on this deceptive quality of Lysias' style, his cleverness, strongly resembles Phaedrus' judgement of Lysias in Plato's Phaedrus. When summarizing Lysias' approach to the topic of love in the speech, Phaedrus says: 'For Lysias has written on one of the beauties being tempted, though not by a lover, but this is just the clever thing about it: for he says that favors should be granted rather to the

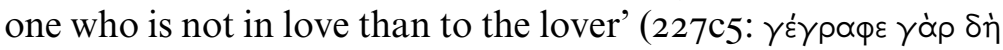

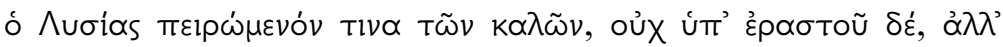

${ }^{48}$ Dionysius' apparently increasing interest in deception that he explores through the figure of Lysias is very curious in this educational and morally heightened context.

I94 


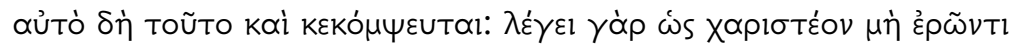
$\mu \tilde{\alpha} \lambda \lambda o v \ddot{\eta} \varepsilon \hat{\rho} \tilde{\omega} \nu \tau l)$. There is a kind of cleverness in Lysias' writing, a simple twist to a commonplace topic, or here a commonplace construction of participating characters, that makes him stand out. Shortly afterwards Phaedrus explicitly

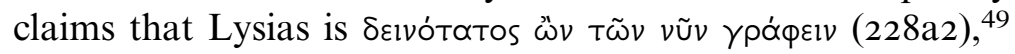
thus stressing a crucial characteristic to Lysias' success and appeal - his 'being $\delta \varepsilon v v o$ s' ${ }^{50}$ It is probably no coincidence that

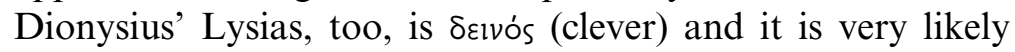
indeed that this concept of Lysias' cleverness has crept into Dionysius' discussion of Lysias' stylistic features through the Phaedrus. While Phaedrus' praise of Lysias is honest, there is no doubt that the dialogue as a whole aims to challenge the view of Lysias as an accomplished writer. As we noticed before, however, Dionysius does not raise the possibility of ironical reading and thus seems to take all praise of Lysias expressed in the dialogue matter-of-factly. Given his criticism of Plato's own style elsewhere, ${ }^{5 \mathrm{I}}$ however, it is also conceivable that by taking Phaedrus' praise of Lysias seriously Dionysius is implicitly undermining Plato's authority when it comes to stylistic recommendations, and is eager to show to his contemporaries and students his supremacy over the philosopher.

In any case, given what we know about the reception of Lysias and the continuous association of his speeches with successful character portraits, it is worth noting that of all the 'ancillary' virtues of Lysias, characterization and charm are the ones that receive fullest treatment and attention by Dionysius. Therefore, it must have been felt by Dionysius that these two features characterize Lysias' style particularly aptly and thus require a more elaborated discussion in the treatise.

49 This claim is reiterated by Dionysius in his Letter to Gn. Pompeius I. Io where he

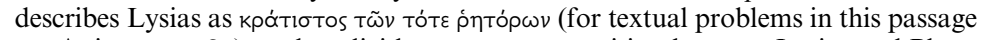
see Aujac I992, 8I), and explicitly stages a competition between Lysias and Plato.

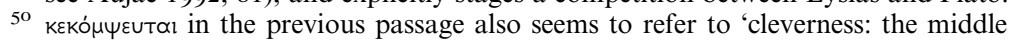

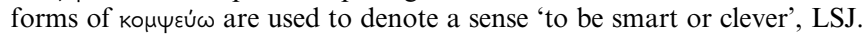

${ }^{51}$ E.g. Demosthenes 5.4-6, 28.6-7. See useful discussion in Hunter (20I I), I I I-84, esp. I63-6. 


\section{Dionysius of Halicarnassus on Lysias}

Lysias' style has propriety, a virtue that Dionysius considers

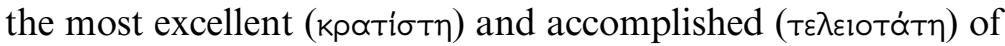
all virtues of style (9.I), but it is also one of the most general virtues mentioned in the list and one which does not emphasize Lysias' idiosyncrasy in any more detailed way. Given the

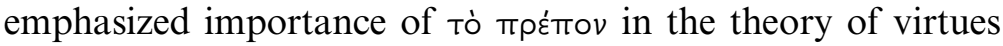
of style (cf. Thucydides 22), this is a virtue that Dionysius was probably compelled to mention in this context, even though there does not seem to be anything particularly Lysianic about it. This might explain Dionysius' choice of language and relative lack of praise of Lysias in this section. Paying mere lip service to Lysias' skill at persuasiveness and naturalness (which is apparently already common knowledge, Io.2), ${ }^{52}$ Dionysius rushes forward to one of the most enigmatic of Lysias' virtues - his charm ( xópı). To conclude his otherwise rather uniform list of virtues with a long digression on Lysianic charm is perhaps the most striking aspect of the essay, ${ }^{53}$ especially as Dionysius seems to use this notion as a way to explore the limits of criticism and artistic creation.

\subsection{Dionysius and Lysias' Charm ${ }^{54}$}

The description of charm (xópıs) in Dionysius' essay On Lysias extends over several chapters of the work and is the longest section dedicated to a single virtue of style. ${ }^{55} \mathrm{He}$ explains Lysias' charm in the following way: 'I will demonstrate one more virtue of this orator, which I consider to be his finest and most important quality, and the one above all which enables

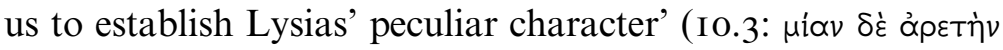

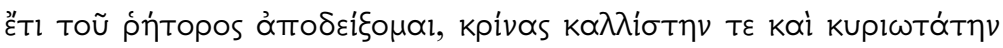

\footnotetext{
$5^{2}$ Wiater (20I I), 3I6-I7 attributes more weight to this section and offers a persuasive analysis of the importance of Lysias' 'naturalness' as opposed to Platonic guise.

53 For Usher (I974), I 8-I9 this gives the entire essay a 'Janus-like quality, looking inwards to the earlier systems of the ancient rhetoricians, of Theophrastus and Hermagoras, and outwards to the later intuitive criticism of Dionysius in the $D e$ compositione verborum, and of the author of the treatise On the Sublime'.

${ }^{54}$ I have discussed elsewhere in more detail the development of the concept of Xópis and its use in literary criticism prior to, and in, Dionysius' work (Viidebaum 20I8).

55 Despite some hesitations, I will translate below the Greek xópıs as 'charm'.
} 


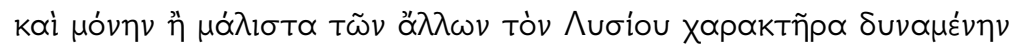
$\beta \varepsilon \beta \alpha 1 \tilde{\omega} \sigma \alpha l)$. Even though nobody else excelled him in xópıs, those who imitated it appeared superior to others because of this quality alone (Io.4). It is 'some sort of charm that blos-

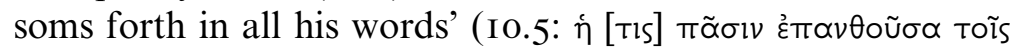
óvó $\mu \alpha \sigma l<\chi \alpha \dot{\alpha} 1 s>$ ) and it is 'something bigger than all words

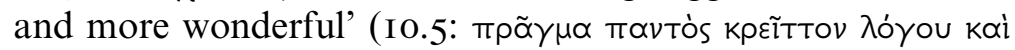

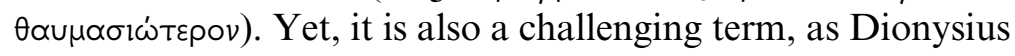
concedes when he says that it 'is very easy to see and it is to everyone, layman and expert alike, manifest, but it is most difficult to express in words, and not simple even for those with

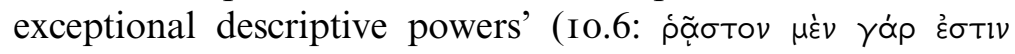

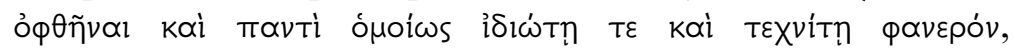

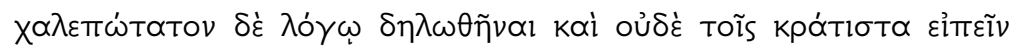

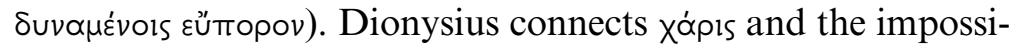
bility of determining in exact terms what it is with other difficult, but most productive, literary-critical terms, such as

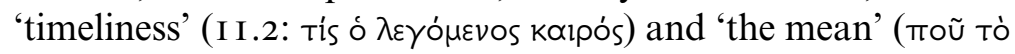
$\mu \varepsilon \dot{t}$ plov). In all these cases, 'it is with senses and not with reason

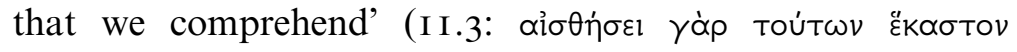

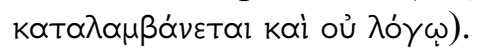

As attested in Philodemus, the term xápis had been used before by the so-called kritikoi in ways overlapping somewhat with Dionysius. Pausimachus (and by extension the whole group of the kritikoi) had argued that xópis appeals to the irrational in us and constitutes the core of any poetic aspiration. ${ }^{56}$ Dionysius also claims that xópıs is an irrational sensation and one that proves for him the most essential quality of Lysias. Beyond the obvious similarities, there are also substantial differences between the kritikoi and Dionysius on this matter. Firstly, Dionysius makes no attempt to actually understand xópis as comprising sounds and, if anything, he is clearly struggling to provide his readers with a clear definition of the concept. To be sure, Dionysius is emphasizing the centrality of

${ }^{56}$ Philodemus On Poems I.83.24-6 and I.89.I4-I6, quoted after the Janko (2000) edition. Gomperz restored 'pleasure' (Xópıv) in column Ioo from P. Herc. 994. col 6, 9-II. 
sense perception, but he is not clear which senses he has in mind (his examples range overall from aural sensations (music) to visual stimulations (painting and sculpture), or how the experience of this phenomenon could be broken down to smaller pieces (in a way similar to the kritikoi). Hence, Dionysius is reluctant to participate in the debate of whether it is sound or sense that should have primacy in oratorical compositions. Secondly, instead of focusing on one particular constituent of xápıs (as the kritikoi do in prioritizing the aural perception of sounds), Dionysius concentrates almost exclusively on a specific author whom he considers to be the best learning-source for xópı - Lysias.

Throughout the section we witness Dionysius working out his way closer towards an explanation of xápis. Since definitions and words are not much help, Dionysius turns to another art where senses are heavily involved - music. Borrowing from music teachers, who advise their pupils simply to cultivate their ear, which is the most accurate criterion

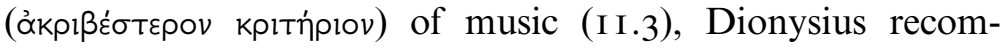
mends his students who wish to learn the nature of Lysias' xópls 'to train the instinctive feeling over a long time with

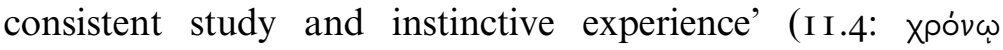

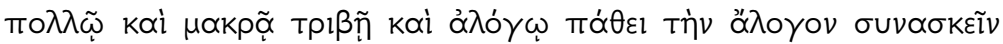
alo $\theta \eta \sigma i v)$. In other words, the first step towards a full appreciation of Lysias' mastery is to simply listen to and read numerous speeches by Lysias without making any attempt to critically discuss or otherwise engage with the work. This constant exposure to Lysianic style will form one's senses in such a way that will eventually lead to a uniform understanding of his particular style and make sure that any non-Lysianic feature will immediately stand out. ${ }^{57}$ How exactly this

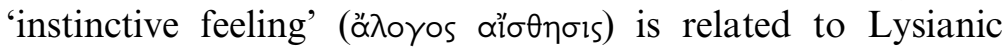
xápıs, however, is not entirely clear. ${ }^{58}$ What emerges, however,

57 Dionysius' treatment of ä $\lambda$ oyos aï $\sigma \eta \eta \sigma ı s$ is discussed with conflicting conclusions by Schenkeveld (1975) and Damon (I99I).

${ }^{8}$ One might also wonder whether Dionysius' method that he recommends for understanding Lysias' xópis could be meaningfully used to determine the qualities and idiosyncrasies of any author, and not just those of Lysias. Indeed, a passage 
is that this method, if that is the right way to call it, is associated with the universal impression of an author and his works, so that Dionysius associates Lysias' xópıs not so much with a particular virtue of style, but rather with the overall effect of his work. ${ }^{59}$

Looking for Dionysius' use of xópıs elsewhere, particularly in the comparisons between different orators, is helpful. It emerges, for example, that Lysias' speeches are compared to those of Isocrates explicitly as having 'lightness' and 'charm' (Isocrates 3.6). Juxtaposed to Isaeus, Lysias, by his simplicity

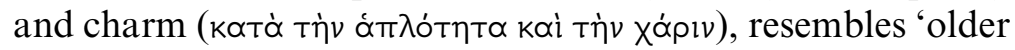
paintings which are worked in simple colors without any subtle blending of tints but clear in their outline, and thereby

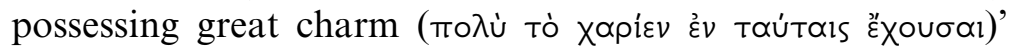
(Isaeus 4.I). From a passage in his Demosthenes (54.8), Dionysius seems to connect xápls with wit, just like Ps. Demetrius had done:

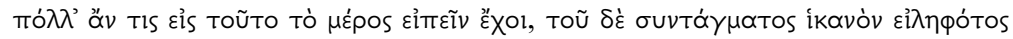

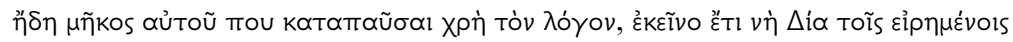

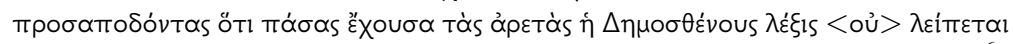

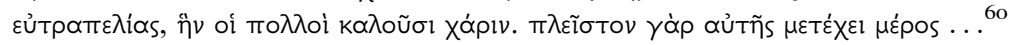

One could say many more things about this subject, but since the treatise itself is already long enough I had better finish my discussion. And yet this

from his essay on Demosthenes (Demosthenes 50.3) reveals that this is the case. Dionysius discusses the melodious composition of Demosthenes and recommends to those wishing to exactly understand Demosthenes' composition ( $\sigma \dot{v} v \theta \varepsilon \sigma 15$ ) to judge the most important and significant individual elements of the composition, the first being melody ( $\dot{\varepsilon} \mu \mu \dot{\varepsilon} \lambda \varepsilon 1 \alpha)$, the best means of judging which is the 'instinctive feeling' ( $\alpha \lambda \circ \gamma \circ$ os alo $\theta \eta \sigma 1 s)$. Dionysius adds, however, that this requires much practice

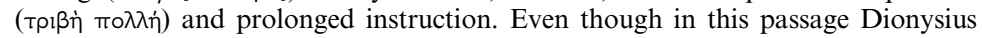
connects the 'instinctive feeling' more precisely with melody in style, thus giving his reader a little more specific information about $\alpha \lambda$ ¿ Lysias, its continued association with the aural aspects of style clearly suggests that Dionysius' thinking in the two works on the topic of 'instinctive feeling' is similar: Dionysius still considers the 'ear' a crucial sense for the evaluation of literary value and artistic success.

59 This overall effect of xópıs could possibly be compared to what Aristotle and Theophrastus seem to have called tò í $\delta$. See Innes (I985), 256.

${ }^{60}$ Usher (I974) prints the text without Reiske's addition of $\langle$ oủ $>$, which completely changes the interpretation of the passage. I follow here Aujac (I988) who adopts Reiske's addition, because Dionysius does not really hint anywhere else in his critical essays that Demosthenes did not have enough charm. 
point ought to be added to what has already been said, namely that Demosthenes' style with its many virtues also does not lack in wittiness, which many call charm. Largest part of that quality ...

Dionysius introduces here xópls as a synonym for $\varepsilon u ̉ \tau p \alpha \pi \varepsilon \lambda i \alpha$ and refers to the authority of 'the many' who have previously made this association. It is very unfortunate that the passage seems corrupt and breaks off at the end. I have adopted, with many hesitations, Aujac's interpretation over that of Usher and included <ou $>$ in the text to indicate that Demosthenes did not lack xápıs. It is, however, also possible that Dionysius concluded his discussion of Demosthenes with a brief reference to xópls and that in this context he would have ended the passage with a reference to Lysias, who has 'the largest chunk of this quality'. Seeing that Dionysius seems to reserve this quality primarily for Lysias, it would not be surprising if also in his discussion of Demosthenes' virtues and of his charm, Lysias would be used as a comparative force. ${ }^{61}$

Throughout Dionysius' critical essays, we are never offered a clear definition of xópı, a quality in which Lysias apparently overpowers everyone else and that seems to best stand for a summary term of Lysias' writing. Dionysius justifies his inability to define and better explain this concept by connecting it to the 'instinctive feeling' and associating it with other supremely important, but extremely difficult concepts of literary criticism. What emerges from this discussion is that for Dionysius xápis is somehow associated with the small, the commonplace and the witty. How exactly these associations work and how students could fruitfully imitate them, all that remains rather unclear. Yet, perhaps the difficulty in defining xópis served a purpose for Dionysius. In its social and educational context, it might have helped Dionysius to reassert the authority of rhetorical teaching and teachers, who will have sat down with their texts and trained their senses to recognize

${ }^{61}$ I regret that I do not have access to Costil (I949), on whose authority Aujac's interpretation seems to rely. There also appears to be a literary tradition that denies Demosthenes 'charm' and without Reiske's emendation of the text Dionysius appears to be flirting with that trend. 
different stylistic features characteristic of different authors. As a reflection of Dionysius' intellectual interests in criticism, Lysias' xópıs might underscore his fascination with these subtle means of persuasion and deception that manage to 'smuggle conviction unnoticed past the listener's senses' (Lysias I 8.3:

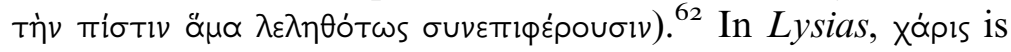
on several occasions mentioned in the company of or as a

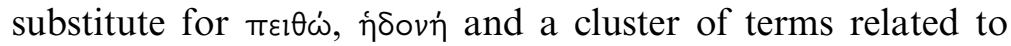
Aphrodite. When Dionysius points to the shortcomings of Lysias' style, for example, he writes that it does not have the capacity to 'force and compel his audience in the same way it is

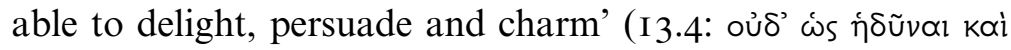

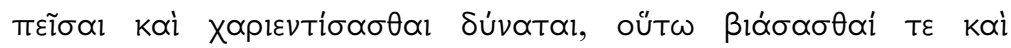

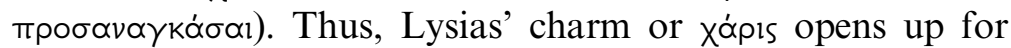
Dionysius and his students a way to see rhetoric as an amusing and delightful activity that is playfully exploring the murky waters of $\pi \varepsilon \imath \theta \dot{\omega}$ (persuasion) and deception.

\subsection{Lysias - a Greek Writer for Rome}

The sections that follow Dionysius' discussion of Lysias' charm ( $\chi \alpha$ '́p) are perhaps best summarized as 'Lysias the

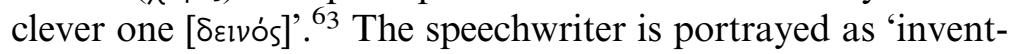

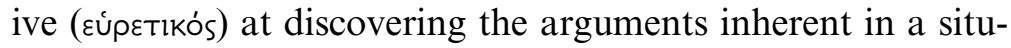
ation, not only those which any of us could discover, but also

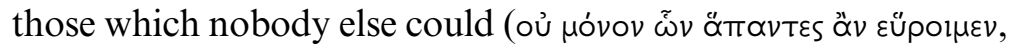

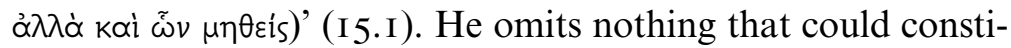

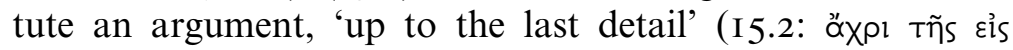

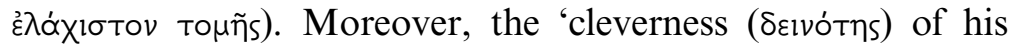
invention is best exemplified in those speeches in which there

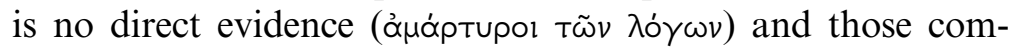
posed upon extraordinary themes ( $\pi \varepsilon \rho \dot{i}$ tàs $\pi \alpha \rho \alpha \delta o ́ \xi o u s$

${ }^{62}$ Dionysius in the section quoted is talking about Lysias' narratives.

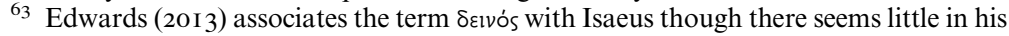
own analysis that would tie this particular concept together with Isaeus in particular (mostly Isaeus is treated, both by Dionysius and Edwards, as a frontrunner for

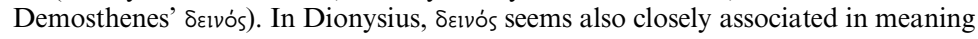
with 'sublime' (üพos); see more in Porter (2015), 395-6. 


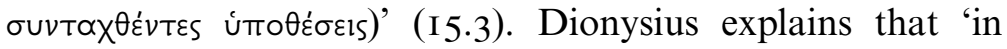
these he furnishes a great many excellent arguments and makes cases regarded by everyone else as hopeless and impossible seem easy and practicable' (I5.3). This cleverness finds its clearest expression on the forensic stage and Dionysius argues that 'in this type of oratory, he is more capable of speaking

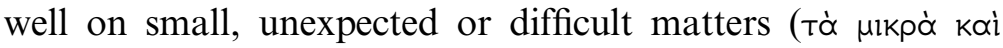

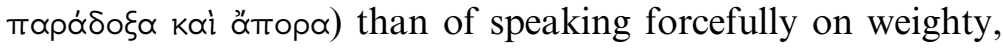
important or straightforward subjects' (I6.3). The fact that Dionysius fails to give any comments or analysis for the examples he cites from Lysias' ceremonial and deliberative speeches shows clearly that Dionysius' interests in Lysias' style are restricted to his forensic work. It might also be, even though Dionysius does not dwell much on this possibility, ${ }^{64}$ that Lysias' forensic speeches are most securely attributed to him in the tradition, whereas speeches from other genres had aroused questions about delivery and authorship. Be that as it may, Dionysius' Lysias is attractive for his ability to invent and twist arguments beyond one's imagination, for bringing unexpected and surprising solutions to complicated and impossible cases, and for talking about small everyday matters with a wide lay audience. These could have been characteristics that many young Romans and Dionysius' potential students might have found very attractive: here was an entertaining Greek author who would not put off students (and Romans?) with his philosophical gravity, ${ }^{65}$ and who at the same time has much to teach about 'playful intellectualism'.

That Dionysius was generally alert to the topic of appropriate audience and styles is clear from his essay Thucydides, where Dionysius comments on the complex style of Thucydides. In response to those who suggest that Thucydides 'can be read with understanding only by the

${ }^{64}$ As far as I see, Dionysius acknowledges the issue of Lysias' performances in a brief remark at paragraph 32 .

${ }^{65}$ It seems that the introductions of Cicero's work may be particularly relevant as reflecting the responses of his contemporary Romans to Greek culture and literature. See Baraz (2012) for a more detailed discussion. 
well-educated' (5I.I), Dionysius claims that 'in confining it to an extremely small minority of readers, they are removing from ordinary men's lives a necessary and universally useful

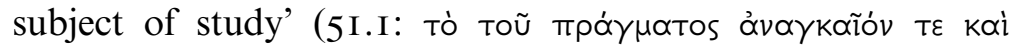

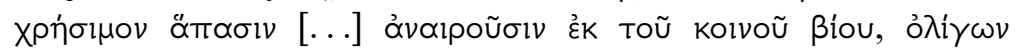

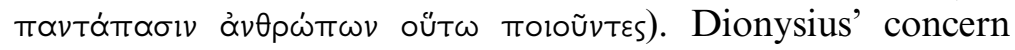
for the 'uneducated' reader is also strongly present in his

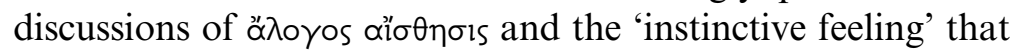
affects the critic and the non-critic alike. It seems fair to say, then, that Dionysius is in favor of clear and simple Attic prose; his criticisms of Thucydides and Isocrates, for example, point to their obscurity (Thucydides) or overly ornate style (Isocrates). It might not be too far-fetched to suggest, then, that this preference of simplicity and clarity also reflects Roman literary tastes and rhetorical education, ${ }^{66}$ and - if true could be interpreted as a confirmation of the above sentiment about the potential attractiveness of an author like Lysias for the Roman audience.

However, this conclusion might appear problematic when we look at what Dionysius explicitly tells us about his intellectual environment and his potential readership. In his $O n$ the Ancient Orators, which served as a broad (ideological) introduction to the critical essays on selected ancient orators, Dionysius claims that the changed appreciation of rhetoric is indebted to 'the fact that Rome was ruling the world' (3.I:

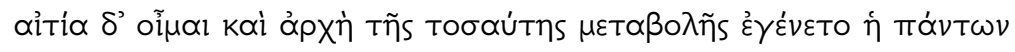

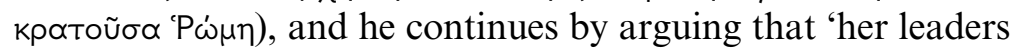
are chosen on merit, and administer the state according to the

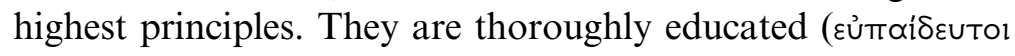
$\pi \alpha \dot{v u}$ ) and in the highest degree discerning, so that under their ordering influence the sensible section of the population

${ }^{66}$ In Suetonius' Augustus (86.I), the emperor's stylistic preference is made clear: 'he cultivated a neat and sober style [...] his chief object was to deliver his thoughts with all possible perspicuity' (Genus eloquendi secutus est elegans et temperatum [...] praecipuamque curam duxit sensum animi quam apertissime exprimere). Hose (I999) emphasizes that Greek critics in Rome had Romans in mind as their intended audience and thus tailored their discourses to the particular tastes and expectations of the Roman setting. 


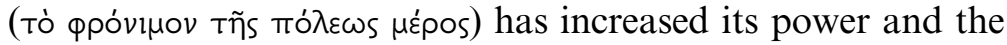
foolish have been compelled to behave rationally' (3.I). In other words, Dionysius claims that the level of education among the populace has risen in Rome and we can expect this to have a direct effect on Dionysius' evaluation of his students and readers. And indeed, Dionysius makes several gestures towards his imagined readership that support his high regard for their cultural education. In his essay Lysias, for example, he characterizes his audience as 'those knowing' or 'connoisseurs' (IO.I: દỉótes) and later on as 'well-educated and moder-

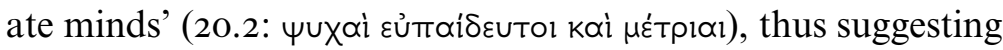
that he has high expectations for the intellectual capacity of his imagined readership. ${ }^{67}$ Yet perhaps these apparently conflicting views of Dionysius' intended audience are not necessarily mutually exclusive. Rome has already demonstrated her dislike for the ornate and excessive Greek style (On the Ancient

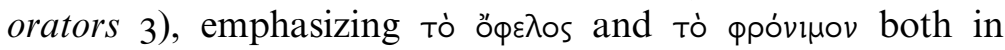
rhetoric and in style. Dionysius, building on this intellectual climate that prefers the simple over the complex, and the useful over the pleasurable, will thus find a favorable audience when commencing his critical essays with the Greek orator that most fulfils these conditions - Lysias. By proposing Lysias as the first role model for style, Dionysius is at the same time fashioning his audience as 'learned' men who already know that it is simplicity and effectiveness, the very virtues Dionysius ascribes to Lysias, that are to be valued highly in oratorical performance. In other words, Dionysius attracts the Roman elite reader to the Greek models by appealing to the virtues to which Romans are already committed and flattering them for having duly recognized these virtues thanks to their wide

${ }_{7}$ More parallels are collected in Hidber (I996), I 20. Wiater (20I I), 270-8 strictly emphasizes Dionysius' elitist approach to education and his readership and demonstrates its connections with his classicism. It is surely true, as Wiater maintains, that Dionysius' writings were addressed to the Roman elite, but we might not want to dismiss the possibility that the Roman elite was not as eagerly invested in classicism as Dionysius' rhetoric invites us to believe. Emphatically labeling one's audience as 'knowledgeable' and 'well-educated' might also have been used by Dionysius to flatter his readers and create a suggestive image for them that would be very difficult to reject. 
learning. Furthermore, if it is indeed true that Rome was suspicious of Greek intellectuals and philosophers and did not have high regard for their abstract argumentation and emphasis on theory, ${ }^{68}$ this might also show Dionysius' discus-

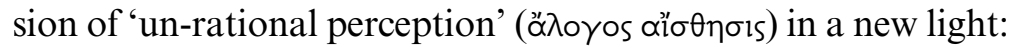
when Dionysius argues that the most important quality of Lysias' style is his charm (xópıs), which according to him depends on this kind of 'un-rational perception' (ä $\lambda$ oyos alo $\theta \eta \sigma 15)$ and cannot be understood through logical/abstract reasoning, Dionysius might in fact have put his finger on the Roman virtue of style par excellence. Even more than the emotion and power of a Demosthenes, this experience-based and sense-dependent charm that does not render itself amenable to theoretical discussion is what might have spoken most closely to the Roman oratorical practice. ${ }^{69}$ Hence, with his notion of 'charm' Dionysius appears to have given the Romans a useful critical tool with which to justify their high regard for Lysias and the kind of rhetoric that is associated with it. ${ }^{70}$

It has been briefly suggested by scholars before, ${ }^{7 \mathrm{I}}$ but has not been followed up by any further examination, that Dionysius' essay on Lysias has a foundational role for Dionysius' criticism of the orators. This is particularly apparent in the first three essays of the project On the Ancient Orators, where essays on Isocrates and Isaeus are clearly

${ }^{68}$ Cicero has made this intellectual climate plain in his attempts to counter these accusations. He discussed this topic in depth in his lost Hortensius, but we see his continued engagement with this environment, for example, in his Tusculan Disputations (2.I). For thorough discussion of this passage, see Gildenhard (2007), I56-66. Griffin (I989), I8-22 offers a fundamental analysis of the Roman suspicions about philosophy in public life, and a very helpful overview is provided recently by Baraz (20I2), I3-43.

${ }^{69}$ Cf. Gabba (1982), 48.

${ }^{70}$ I take Wisse's (I995) discussion of the Atticist movement as originating among the Romans as potentially strengthening my argument.

${ }^{71}$ E.g. Bonner (I 939), 27. Most recently Wiater (20I I), 32 I ff. Wiater (20I I), chap. 5 offers also a fascinating reading of Dionysius' complicated relationship to Plato and Platonists, and how Dionysius' treatment of Lysias is aimed to counter the stylistic observations of Platonists. In many ways his observations pave the way for the present discussion of the rivalry between Plato and Dionysius over the position of leading literary critic on rhetorical education. 


\section{Dionysius of Halicarnassus on Lysias}

written against the backdrop of Dionysius' work on Lysias, and the prominent presence of Lysias in Dionysius' critical work seems to be a strong indication that Lysias is used as a point of reference by Dionysius to develop and clarify his views on other orators.

Indeed, in Dionysius' essays on Isocrates and Isaeus, Lysias is clearly the central figure with whom both Isocrates and Isaeus are compared. In fact, both essays seem to reveal characteristics of Lysias as much as they tell us about the style of Isocrates and Isaeus. In the essay on Isocrates, for example, Dionysius runs quickly through the list of terms that he had

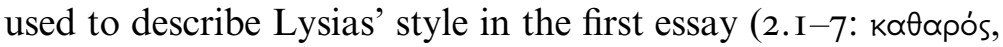

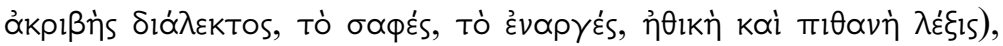
employs the same structure for discussion, and expands the list where Isocrates differs from Lysias (e.g. 2.4). Despite his appreciation of Isocrates' writings, Dionysius keeps coming back to Lysias as the point of departure for his discussion of style, and especially forensic style, throughout the essay. ${ }^{72}$ The same observations apply to Dionysius' essay on Isaeus. While Isaeus is positioned between and compared with both Lysias and Demosthenes, Dionysius' underlying comparative method follows the terminology that he had introduced in the first essay on Lysias: Isaeus' language is 'pure, precise, clear, standard, vivid and concise, and also persuasive, appropriate to the subject and suitable for law courts not less than that of Lysias'

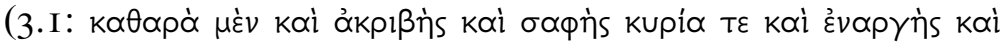

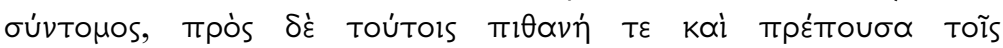

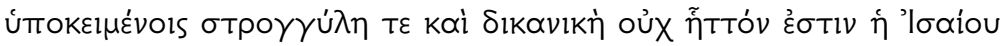
$\lambda \varepsilon \dot{\varepsilon} 15$ Tñs $\Lambda$ ưíou). In his summary of the two orators Dionysius concludes, for example, that Isaeus aims more at artistic effect and forcefulness, while Lysias is more natural and charming

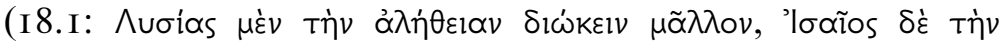

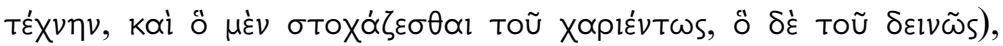
referring back to the characteristics introduced in his essay. These examples clearly show that the terminology and

${ }^{72}$ The whole discussion of style, for example, is summarized in paragraph io by a comparison with Lysias. 
language of comparison in these two essays require a close familiarity with Dionysius' essay on Lysias, where these features of style were first introduced and explained in more detail. His first essay, then, instead of showing undeveloped and uninteresting rhetorical criticism, might be better understood as a way for Dionysius to set the stage for the following critical discussions and to use the figure of Lysias, the most straightforward example of plain style, to shed light on the basic structure and critical language that he is going to adopt in his critical essays.

The critical language introduced in Dionysius' Lysias is also reflected, even though to a somewhat lesser extent, in his later work Demosthenes. Lysias is used as the representative of plain style and opposed to Thucydides who is the figure for grand style. When introducing Isocrates and the middle style, the main object of attention in this essay, Dionysius again makes productive use of Lysias and the characteristics of style introduced in Lysias to show how representatives of the middle style are able to make use both of the plain and the grand style. Isocrates' style, for example, is described as having the Lysianic purity (тò $k \alpha \theta \alpha \rho o ́ v$ ), clarity (тò åkpıßśs), use of

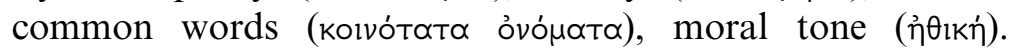
Furthermore, it is persuasive $(\pi \imath \theta \alpha v \dot{\eta})$, pleasant $(\dot{\eta} \delta \varepsilon \tilde{i} \alpha)$ and

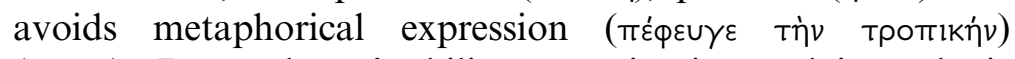
(4.I-2). Demosthenes' ability to write in a plain style is described with the same critical vocabulary familiar from Dionysius' previous essays. His forensic style is as pure

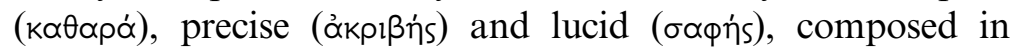
standard words ( of Lysias. It is also concise ( $\sigma \dot{v} v т о \mu о \varsigma)$, terse ( $\sigma т \rho о \gamma \gamma \dot{u} \lambda \eta)$, full of

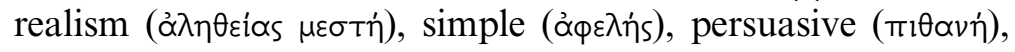

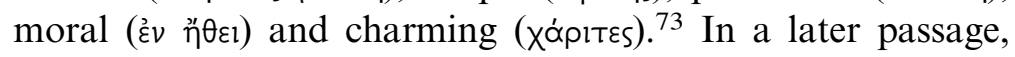
Demosthenes' style is described as incorporating features of the plain style (tò бaфśs, tò koıvóv) where appropriate and the elements of the grand style when needed (34). In sum,

73 Demosthenes I3. I-2. 
Dionysius' discussion of Demosthenes' style is in certain respects drawing on the discussion of Lysias' style, and he is certainly making use of the same critical terminology in this later work.

Finally, Lysias and Dionysius' first critical essay Lysias have a prominent position in Dionysius' essay Dinarchus. In the beginning of the essay, Dionysius quotes the judgement of Dinarchus by another critic, Demetrius of Magnesia, who was active at the time of Cicero, thus a few decades before Dionysius. ${ }^{74}$ Demetrius appears to make use of a similar technical language to that we see in Dionysius: Dinarchus is described as persuasive, his diction portrays moral character in standard language, and is capable of arousing emotion. ${ }^{75} \mathrm{It}$ is curious that the first characteristic that Dionysius quotes from Demetrius' work is Dinarchus' charm which he compares

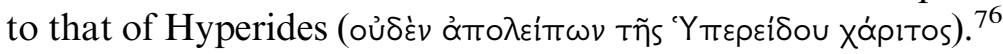
From this quotation, which is admittedly taken out of context and also intended to discredit the older critic, we get a sense that Demetrius considers xópıs a basic stylistic category, one that is easy to understand and does not require further explanation. Dionysius could not have disagreed more. Also, many orators are measured according to their xópis and this quality does not seem in any way connected (in Demetrius' quotation) to Lysias. It is perhaps not a surprise then that Dionysius finds fault with Demetrius and his approach to Dinarchus. Indeed, Dionysius is unhappy with Demetrius' criticism and complains that it is neither precise nor accurate; Demetrius has used the common critical terminology without contributing to the scholarship. ${ }^{77}$ Even though in what follows, Dionysius makes use of a very similar critical terminology, referring to terms like lucidity, naturalness, charm and animation, his

74 On Demetrius of Magnesia, see Mejer (I98I).

75 Dinarchus I.3:

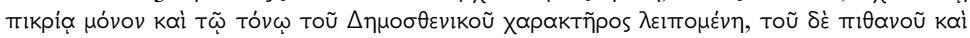

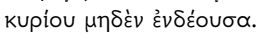

${ }^{76}$ It is worth noting that the occurrence of xópis in Demetrius' critical work on the orators indicates that a larger conversation occurred around that time on the concept of $x$ ópıs and its use in contemporary rhetoric.

77 Dinarchus 2.I. 
comparative criticism and close analysis of original passages make his judgement more systematic and informative. In passages where Dionysius introduces critical terminology, his early work on Lysias seems implicitly evoked for comparison and context. ${ }^{78}$ All in all, we notice a general trajectory of critical language from Dionysius' earliest critical essay on Lysias until his late essay on Dinarchus. This 'tool-kit' is enlarged throughout his numerous essays, but some of the most important features introduced in Dionysius' Lysias remain at the center stage of his critical outlook throughout his critical oeuvre.

This position runs somewhat counter to the arguments advanced by Bonner in his work on Dionysius' essays, where he aims to map out the development of Dionysius' critical method throughout his work on ancient orators. ${ }^{79}$ The evidence Bonner is drawing on, explicit examples from the essays where Dionysius adds new elements or elaborates on existing elements of his critical method, is clear and confirms Bonner's observations. It is surely true that Dionysius incorporates in the course of his writing new elements that show him as broadening his critical method and outlook. Yet, the fact that Dionysius' essays on the orators grow in sophistication as he emphasizes different elements in their styles might also be read to suggest that this was exactly what Dionysius' essays were meant to do from the start: Dionysius seems to invite us to follow the ever more complicated details of style and method as he works his way through the different authors, and thus asks us to build upon the knowledge we have acquired from reading the previous author and to apply and elaborate that on the subsequent authors he is discussing. The implicit crossreferences in his essays, as shown above for example in the essay on Dinarchus, seem to corroborate this conclusion. In fact, strategic thinking seems to be at the core of Dionysius' selection of the ancient orators: every figure enables him to pursue a different agenda and emphasize various aspects of

\footnotetext{
${ }^{78}$ E.g. Dinarchus I.2, 6.2. 79 Bonner (I939), 23, I03.
} 


\section{Dionysius of Halicarnassus on Lysias}

Greek oratory and rhetoric that he perceived to be relevant to his Roman environment. ${ }^{80}$ While Lysias is the first in line and introduced as standard for style, Isocrates (as will be argued below) is important for giving the direction and moral boundaries for rhetoric. Isocrates also comes to stand for the teacher figure who serves as an intellectual for the community, effectively laying out Dionysius' own image as a teacher and critic in Rome, the cultural hub of the world. Isaeus is included as an intermediary between Lysias and Demosthenes, a teacher not of the city as a whole, but of the complete orator Demosthenes. $^{8 \mathrm{I}}$

Lysias, then, is the earliest and the first orator treated in the collection, and he has therefore an important role to play in the whole project. Through this orator, Dionysius sketches out the terminology of style that he adopts for all following essays and introduces his critical method to rhetoric. The subsequent treatments of other orators will expand and modify, but not substantially change the outlook and critical 'tool-kit' introduced in that first essay. As such, Dionysius' critical essays seem to function almost like protreptics to literary and rhetorical criticism. ${ }^{82}$ Dionysius is guiding his reader towards a competence in literary and rhetorical criticism by feeding them with just enough information at each stop/essay to get a sense of increasing knowledge and understanding of the complicated field of rhetoric. And Lysias, the first author Dionysius discusses in detail, becomes a model of style against which all following orators are measured.

${ }^{80}$ In his manifesto On the Ancient Orators Dionysius also promises separate essays on Hyperides and Aeschines in addition to those on Lysias, Isocrates, Isaeus and Demosthenes, but these, it seems, were never written.

${ }^{81}$ On Isaeus, see also Edwards (2013).

${ }^{82}$ Wiater (20II), chap. 5 discusses Dionysius' criticism as dialogical and participatory, rightly drawing attention to the different voices that constitute his critical writing and to the cumulative effect of building a community that this style of writing will have on its readers. The point here is slightly different: Dionysius plans his critical essays to draw in students from the first essay onwards and to keep them going from the first to the last to get a full sense of his rhetorical program. Leigh's account (2004) on the preface of Quintilian 6 seems to work towards a similar argument. 
The inclusion of Isaeus over, say, Antiphon (the earliest Attic orator that we have evidence of ), may seem surprising. Indeed, it is curious that Dionysius decided not to include Antiphon in his list of orators, especially since this orator had been associated with forceful style before (Thuc. 8.68. I) and is credited by Dionysius elsewhere with innovative style (e.g. ad Amm. 2.3.). He would have been in a good position to claim a spot in his project. ${ }^{83}$ Dionysius asks himself this very question and responds, rather hesitantly, that Isaeus is admittedly only included for his alleged effect on Demosthenes (20.5: 'I think the seeds of genius [...] are present in this man', my emphasis). When Dionysius refers elsewhere, however, to the illustrious orators of that period, he readily substitutes Isaeus with Antiphon. So, for example, in his essay Thucydides, where he lists the three - Antiphon, Lysias and Isocrates (in that order) - as the 'leading orators of the day'

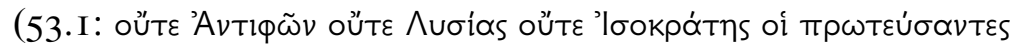

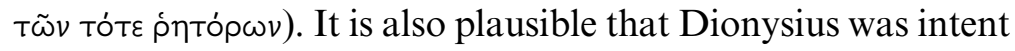
on commencing the project with Lysias and precisely for that reason did not want to include an older orator, Antiphon, who on a chronological basis would have had to precede Lysias and thus become the measure against which all following orators would be assessed. In order to create a neat chronological sequence and still keep Lysias in the first position, Dionysius decided to include Isaeus and leave out Antiphon.

There is something else about Lysias that might have been relevant for Dionysius: he was not an Athenian citizen. Though born and raised in Athens, Lysias was not and never seems to have become an Athenian citizen. ${ }^{84}$ In fact, he is the only non-Athenian orator included in the project $O n$ the

${ }^{83}$ See Usher's brief note about this (I974, I70).

${ }^{84}$ Thrasybulus' block grant of citizenship after the restoration of democracy in 403 BCE was very likely to have been blocked immediately by Archinus' graphe paranomon (prosecution for proposing an unconstitutional decree), thus giving no interim period for Lysias to resume citizenship, deliver speech I2 and then lose citizenship again. On Lysias' citizenship, see Todd (2007), I4-I6 with further bibliography. 


\section{Dionysius of Halicarnassus on Lysias}

Ancient Orators. ${ }^{85}$ Therefore, in addition to what has already been said about Lysias' importance for Dionysius, it is worth considering the possibility that Lysias played such a crucial role in his critical essays also because he, like Dionysius himself, was not a citizen of the city (Athens/Rome) where he lived and reached his renown. Furthermore, Lysias' dedication to his 'host-city' Athens is widely on display in his twelfth speech, Against Eratosthenes, which is the only one in the corpus that can be confidently ascribed to Lysias himself (and as such the only non-logographic speech). To a large extent, the speech is staging a pronounced contrast between citizens and metics (under the Thirty), ${ }^{86}$ where the former have become the villains and a threat to the city and the latter (in particular Lysias and his family, of course) emerge as ultimate benefactors and restorers of Athenian democracy and its moral standard. ${ }^{87}$ The emphasis on the value of committed foreigners to the city is something that would have been relevant also to Dionysius and his fellow teachers, intellectuals and writers who hailed from the margins of the empire to contribute to the intellectual life of Rome. Whatever Dionysius' feelings towards Augustus and the political regime in Rome were at the time, ${ }^{88}$ his

${ }^{85}$ We ought not to forget, of course, that Dinarchus was a Corinthian, educated (like Lysias) in Athens, and is the subject of Dionysius' essay concerned primarily with ascription and authorship of the Demosthenic corpus. Dinarchus was not, however, included in Dionysius' project On the Ancient Orators and Dionysius admits himself (Din. I.I) that the addition of this orator has been something of an afterthought.

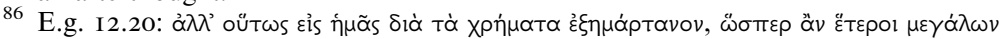

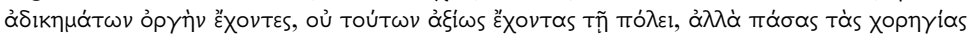

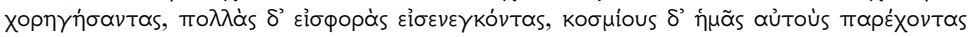

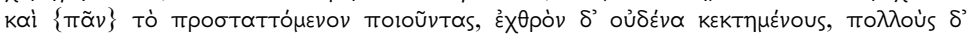

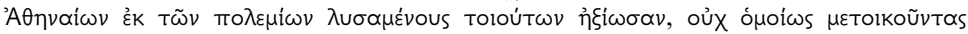

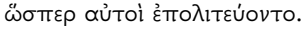

87 That the city has been hurt by its own citizens (and not by external forces or metics) is a frequent theme of the speech (I2.2: 'the defendants' hatred for their own city'; 39-40; 5I: 'this man treated the city as his enemy and your enemies as his friends'; 68, 78, 8I-2, 89, 92, 96, 99). The Thirty apparently had high moral goals (I 2.5: 'claiming they needed to cleanse the city of wrongdoers and redirect the remaining

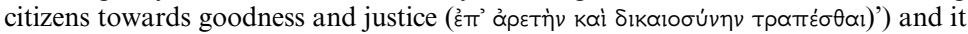
is the underlying goal of the speech to demonstrate the falsity of their moral enterprise.

${ }^{88}$ On Dionysius' political views towards Augustus, see Wiater (20I I), 206-I6, and most recently Pelling (20I8). 
Lysias - a Greek Writer for Rome

manifesto On the Ancient Orators clearly indicates a strong belief in Rome as the center of the world, and in himself as contributing to the flourishing of that city. Indeed, sometimes it takes a foreigner (Lysias/Dionysius) to restore and promote the values of the great city (Athens/Rome) ... 